\title{
The Relationship Between Indigenous Pastoralist Resource Tenure and State Tenure in Somalia
}

\author{
Jon D. Unruh \\ McGill University
}

\begin{abstract}
Indigenous resource tenure systems in Africa have evolved to meet the constraints and opportunities of often difficult biophysical environments, while facilitating the operation of complex spatial and temporal land use patterns. Traditional systems provide security of tenure in culturally relevant ways that permit adaptation to new circumstances. On the other hand imposed tenure structures in Africa have often not strengthened individual rights and have often blocked indigenous tenure development and adaptation in response to new situations.

Pastoralists in Africa have in particular been negatively impacted by the imposition of national tenure systems which in many cases have served to marginalize nomadic populations, with repercussions in land degradation, food security, and instability.

In Somalia the transient resource rights and resource use arrangements that are critical to transhumant pastoralism were ignored in the formulation of the national tenure regime which favored crop cultivation. The results were increased land degradation, resource use conflicts, declines in pastoral production, and impacts on Somali clan alliances which in many cases regulate rational resource access and use.

Somalia posses the greatest proportion of pastoralists in Africa. Transhumant pastoralism, as the most widespread agricultural enterprise in the country, will play a critical role in food production for the foreseeable future. However the relationship between indigenous pastoralist tenure and state imposed tenure, has in many locations decreased the ability of pastoralism to reproduce itself, thereby compromising the rational utilization of very large areas of rangeland interior, which have very few alternative uses.
\end{abstract}

\section{Introduction}

The majority of those engaged in agricultural activities in Africa operate under indigenous resource tenure systems. Contrary to the image portrayed, these systems do not exist as "simplistic stereotypes" resistent to change (Bruce 1986). Rather, they are particular to specific ethnic groups and agro-ecologies that have evolved over centuries as a result of the interaction between culture and environment. There is enormous diversity in African cultures and environments and these have created a wide assortment of resource tenure systems. The presumption of antiquity and permanence in these systems is often incorrect (Bruce 1986). Change is pervasive as 
different systems adapt in different ways to provide tenure security (control over resources) in arrangements that make cultural and ecologic sense to indigenous groups (Lawry 1989). Some of the variables which impinge on the development and adaptation of these systems include: the spatial distribution of resource quality, climate, and ecology; the type and level of agricultural technology; population density; crop species; markets; kinship and settlement patterns; the religious significance of land and other resources; political organization; and patterns resulting from ethnic conquest, dominance, and rivalry (Bruce 1986).

For pastoralist tenure systems in Africa, the history, climate, and increasingly fragile economies of many locations (especially in arid regions) strongly suggest against dividing resource use and access up into fixed parcels to be used exclusively by a particular person or set of persons with defined resource boundaries (Riddell 1982; Ibrahim 1987; Swift 1991), especially where other economic opportunities are lacking. Spatial and temporal overlapping resource utilizations are common in Africa, particularly among transient users such as transhumant pastoralists. Transient rights of access to resources can be backed either by law, or, by what Riddell (1982) calls subjectively valued, time-honored rights, or "law-in-action". In other words, what is in place are the "ad hoc arrangements that develop to meet the variety of situations in which people find themselves" (Riddell 1982). It is these preferential behaviors that outline the rules of indigenous resource use that are actually in operation, and which can precede, and in many cases operate instead of, or mixed with, formal state tenure (Riddell, 1982).

In the last century commercialization of agriculture and the associated new technologies imported during the colonial and post colonial periods have had impacts on indigenous tenure systems such that virtually none has remained completely unaffected (Bruce 1986). During the colonial era and after, central governments frequently declared all unused land (and occasionally all land) to be the property of the government, to be allocated according to mandate. Attempts at replacing indigenous tenure regimes with state tenure systems has had unexpected repercussions arising from changes in access to resources (Swift 1991). This paper will examine the indigenous resource tenure system traditionally employed by Somali pastoralists, and the relationship between this system and the state imposed system in place prior to the collapse of the Somali state in the early 1990s.

\section{Adaptation to Biophysical Resources}

\section{Indigenous Pastoralist Tenure in Somalia}

For nomadic pastoralists the best protection against unreliable precipitation is access to extensive territory containing quality forage and water sources. As with other pastoral systems on the Horn (Ibrahim 1987), mobility and flexibility are required to make good use of meager range resources in Somalia, thus pastoral units of production are small and widely dispersed (Samatar 1989a). The logic of the pastoral economy is to minimize risk in order to secure preservation of the household (Samatar 1989b; Samatar 1989a). As an adaptation to ecosystems in which forage and water resources are critical parameters, transhumant herding largely depends on dry season forage within reach of dry season watering points (Scudder 1989; Breman et al 1979). When this forage is depleted or access to it and nearby water supplies are interrupted, the result can be land degradation, livestock 
dieoffs, conflict, and rapid sales as pastoralists seek to realign resource access arrangements, utilize already marginal land, and cope with reductions in herd viability.

\section{Lineage and Resource Use}

Genealogy is the main organizing principle of the Somali social system, including tenure relations (Samatar 1993). This arrangement is characterized by competition and conflict between clans, lineages and their further segmented units (Laitin and Samatar 1987; Clark 1993; Samatar 1993). Each level of segmentation defines the rights, obligations, and relative standing of households and individuals (Samatar 1993; Laitin and Samatar 1987; Gunn 1990). The multiple layers of alliance in which each nomad finds him/herself reveals the different levels at which competition occurs and the need for security exists (Bennett 1991). Because every person is a member of several lineage segments or subgroups which have alliances with lineage segments of other clans, a particular nomad's political allegiance is constantly shifting. A pastoralist's own situation with regard to the needed access to resources, along with political and economic factors, determine the relative importance of these various identities (Bennett 1991). As conditions and situations change so does a nomad's allegiance. Such an arrangement however serves the pastoralist poorly in interactions with the state (Markakis 1993).

Such segmentation and structural instability are common among nomadic pastoralist societies, primarily due to the considerable territory required for grazing (Laitin and Samatar 1987; White 1990; Bennett 1991; Storas 1990). Such organizational flexibility, or "low investment politics" is a general feature of east African pastoral communities, and appropriate to highly variable, unpredictable natural environments and external situations (DysonHudson 1985). Access to restricted or scarce resources in somalia are thus primarily based on membership in a lineage or religious community capable of defending such rights against competitive groups. Resource rights are identifiable by such membership, rather than by geographic boundaries and are a fundamentally different concept than that of direct territorial ownership, use, and access where a boundary establishes where the rights of one group or individual begin and those of another end (Samatar 1989b). Thus in Somalia there exist general 'home areas' with boundaries that do not function according to the western definition of 'boundary' (Figure 1). In the ecologically fragile arid environments, such an arrangement is important in mitigating land degradation and ensuring long term productivity of range resources (Ornas 1990; Samatar 1989b; Poulsen 1990).

\section{Flexibility in Resource Access}

Land traditionally is not alienated from the clan in Somalia. If a pastoralist from a neighboring clan is allowed to use grazing resources, the person becomes allied with the clan, rather than land being removed from the clan's territory (Gunn 1990). Thus there exists a dynamic overlap in the territorial orbit of different clans. This overlap increases in times of drought as members of one clan may intrude into another clan's territory when its own grazing and watering resources become scarce, provoking mutual hostilities (Bennett 1991). While such a cycle of resource scarcity and territorial intrusion and confrontation among clans and segments thereof have always been a part of Somali pastoralism, such conflicts have increased in recent decades due to declining ecological conditions (Bennett 1991) 
increased in-access to traditional resources, and modern weaponry.

Pastoralist households have access to social-ecological zones of changing size and shape, depending on the ephemeral agreements between various lineage segments and the relative ecological endowment of different grazing locations (Helander 1986). These zones represent a perception of both social and biophysical space where the correlation is not one to one. This increases the choices available in decision-making. Pastoralists must consider tradeoffs associated with moving to good pasture where bad social relations exist, versus an area with good social relations but a poorer biophysical environment, and variations between these. Thus the mix of genealogical and personal relations, along with seasonal resources, combine in different ways to govern herding and migration decisions (Helander 1986).

The lineage system and personal relationships between pastoralists facilitates a degree of insurance against stock loss by the possibility of borrowing animals from fellow stock-owners with a shared lineage or with whom exchange relationships exist. This occurs through the exercise of rights and obligations involved in such relationships, and carries with it an assurance of reciprocity (Poulsen 1990; Samatar 1989b; Ornas 1990).

\section{Resource Use in Pastoralist-Farmer Interactions}

In Somalia small-scale cultivators on both rainfed and irrigated land commonly allowed widespread pastoralist access to available forage (grazing, fallow, and crop remnant) and water resources. This was based primarily on exchange relationships, and ethnic and historical connections between farmers and pastoralists which allowed such arrangements to be mutually beneficial. Small-scale farmers in the Shalambood area of southern Somalia (an irrigated zone) emphasized that banning livestock from irrigated areas, and even fining livestock owners to prevent canal damage, would be unjust if there were not alternative grazing and watering areas set aside for livestock. Operators of large-scale, mechanized and intensive agriculture however were much less willing and able to allow similar arrangements. In general, agreements granting pastoralists access to farmers' land served to build relationships between clans, sub-clans, lineages, and families that could be activated for mutual benefit in less favorable times, ie., drought, famine, and conflict.

Timing is important to effective tenurial arrangements involving the sharing of land and water resources between pastoralists and farmers. In the south of the country during the final weeks prior to the primary harvest, when herds were beginning to move toward dry season grazing and watering locations containing cultivated fields, pastoralists held their herds in the bush just beyond the cultivated zones, were they paid for watering at private wars until the harvest was complete. Their willingness to accommodate farmers in this way (Salisbury 1988) was no doubt due to the expectation that longstanding relationships might be jeopardized, but also that farmers and local authorities were willing and able to punish violators. Pastoralists in the area for the most part attempted to avoid generating ill will from farmers due to trampled crops.

The accommodation of significant numbers of livestock within irrigated areas in Africa is usually viewed by development planners as antithetical to the rational use of riverine land. However, the colonial developers along the Shabelli river apparently recognized the desirability of permitting tenure relationships allowing pastoralists seasonal access of riverine resources. During the heyday of the Italian operation of irrigation schemes 
along the southern reach of the Shabelli, the arrangement between Italian landowners and local farmers set the following priorities for water allocation during the course of the dry season: first human consumption, then stock watering, and if water was still available finally irrigation maintenance of cash crops. A group of private canal guards enforced these allocations (McGowan et al 1986). The guards were also charged with ensuring that livestock did not break down canal walls while grazing along their banks. If livestock did damage canals, the owner of the animals was fined or punished. Another feature of the irrigated area at that time was that 50 metres were left in grass along either side of the larger primary canals and were used for livestock grazing. Following independence the Ministry of Agriculture maintained a similar system of livestock accommodation for a time.

Subsequent to independence, the state assumed control over water management and access to land. Overall population and agricultural activity in riverine areas increased, and as a result many of the grazing zones alongside the major canals (other than marshy locations) were put under cultivation. At the same time the canal guards were less of a presence and less reliable, and the overall irrigation infrastructure deteriorated significantly. By the late 1980s many small-scale farmers cultivated under rainfed conditions or erratic irrigation. Nevertheless livestock continued to have some access to available land and water resources in the dry season.

\section{Livestock Development Efforts}

\section{Development, \\ State Formation, and Pastoralist Resource Tenure}

With few exceptions, livestock development efforts in subSaharan Africa have had two general objectives: increasing animal output for market, and rangeland conservation (Bennett et al 1986; Swift 1991). Changes in land tenure are usually considered instrumental, with communal tenure singled out as a leading constraint. Many programs pursued tenure reforms to reduce multiple resource use and access claims to specific grazing areas (Bennett et al 1986). Such a disposition toward individualization--especially notable in range conservation projects--operates with the rationale that only under individual tenure will herders use self-restraint in balancing herd size with carrying capacity, and abandon the notion that pastures exist elsewhere when depleted locally (Bennett et al 1986). However tenure reform often has not been effective in either growth of marketable livestock products, or conservation (Bennett et al 1986). One of the more important reasons for this is the need for transience in resource use given the very high degree of spatial variability in rainfall patterns, and the quick response needed by pastoralists to take advantage of such a variable environmental base. Thus geographically prescribed land resources may only have use value for a limited time in any season (Bennett et al 1986). Cyclic transhumant movements between seasonally available water and grazing resources are difficult to connect to individual tenure, which in most cases requires a substantial technical infrastructure (Bennett et al 1986).

\section{Pastoralism and State Formation}

The incorporation of pastoralists into state structures on the Horn has resulted in political marginalization and a loss of autonomy, with pastoral 
lands partitioned among the several colonial states and Ethiopia. Most borders on the Horn were made through rangelands, and as a result pastoralist peoples were frequently divided between several states. Somalia is the worst example of this. Ethnic Somalis were divided between five different states: Ethiopia, Djibouti, British Somaliland, Italian Somalia, and Kenya. Figure 1 illustrates cross-border pastoral migrations. Attempts at altering spontaneous movement into different resource zones contained in these states altered the process of adjustment that maintained a balance between people, land resources, and livestock that is necessary for survival and avoiding land degradation (Bruce 1986; Markakis 1993).

Doornbos (1993) offers an insightful analysis as to how the political marginalization of Somali nomads came about in the course of state formation, given that the majority of the population are pastoralists, and vast areas of the country are not productively cultivable. In Somalia as in a number of African states, the greater part of political power came to reside within the emerging urban-based political and bureaucratic elite, whose members considered themselves to be in a position to re-design patterns of political involvement. This was done without consideration of the indigenous arrangements which traditionally facilitated resource access and conflict resolution, including disputes over resource tenure.

The process of marginalization occurred with the subordination of pastoralists and subsequent attempts by herders to escape this subordination. The latter was pursued by resorting to informal ways of claiming resources, and/or informal and subsistence approaches to non-compliance (Dornbos 1993). Urban-based groups that attempted central control over pastoralist activities saw pastoralism not as a viable livelihood and mode of land use, but as a nuisance, threat, or as a resource to be harvested (also de Bruijn and van Dijk 1993). However nomadism has considerable ability to evade attempts at external control, complicating the harvesting of pastoral production for concerns of the state. Thus interventions were required in order to access this production, and various development efforts aimed at pastoralists attempted just this (Dornbos 1993). On the other hand if development activities were to have instead strengthened indigenous institutions, or to have allowed their continuing development and adaptation, this would have increased the ability of nomadic pastoralism to evade control. This would have gone against the interests of the emerging elite, and the prevailing development thinking at the time (Dornbos 1993).

\section{Land Legislation and Registration}

\section{The State Tenure System and Pastoralism}

The national land tenure system in place in Somalia was unrelated to the traditional tenure arrangements practiced by pastoralists and small farmers, which were in many cases the defacto arrangements many herders and farmers pursued with each other (Unruh in press; Roth and Unruh 1990).

The 1975 Land Reform Act took precedence over indigenous tenure regimes, and was formulated to give advantage to state enterprises and mechanized agricultural schemes; with limited rights accorded to small farmers, and no rights given to pastoralists other than those included in government sponsored cooperatives and associations (Roth and Unruh 1990; Samatar 1989b; Laitin and Samatar 1987). Sections of the 1973 Unified Civil Code abolished traditional clan and lineage rights of use and access over land and water resources (Hooglund 1993). All land in Somalia was declared 
to be state owned and administered by the Ministry of Agriculture (Samatar 1989b). Arable land could be leased from the government, however pastoralists could no longer claim use or access to land they previously depended on (Gunn 1990).

Obtaining leases to land involved a land registration procedure that was cumbersome, required much time and money, was centralized in Mogadishu, and was most easily used, abused and manipulated by well connected officials and their associates (Unruh in press). This allowed non-locals to gain title to large tracts of land customarily used by pastoralists and small-scale cultivators, because the latter two groups were less familiar with the registration procedures, and in many cases were unable to compete in terms of the political and capital mobilization necessary to complete the land registration process (Samatar 1989b). Dislocated pastoralists and agriculturalists then shifted to use more marginal (and easily degraded) land resources.

A frequent use of newly registered large holdings was as 'fodder farms'. Parcels of land, previously used for dry season and drought grazing by pastoralists, and usually in or near riverine areas, would be registered, enclosed and guarded, and pastoralists charged a fee for access to the natural pasture. This often resulted in violent conflict as nomads were unwilling to pay for what they previously had access to for free.

\section{Cooperatives and Associations}

Under the Said Barre regime the creation of cooperatives was part of the effort to construct a socialist economy. The 1974 Law on Cooperative Development originally intended to facilitate scientific management of the rangeland and rework indigenous pastoralist tenure arrangements so that nomadic groups would share scarce range resources peacefully and efficiently (Laitin and Samatar 1987). Basically the idea was to promote the vegetative recovery of grazing lands and the creation of new watering holes. Fourteen cooperatives were created, with each participant family being allocated an exclusive 500-750 acre grazing area, with common lands available in times of drought. The plan was that when these cooperatives were fully in place the government was then to provide health and educational services and a marketing outlet for livestock (Laitin and Samatar 1987).

In the late 1970s more ambitious range cooperatives were attempted. With external assistance the Northern Rangelands Development Project got underway in 1977, with the Central Rangelands Development project following in 1979 (Laitin and Samatar 1987; Bennett et al 1986). Both projects encouraged nomads to create associations to discuss rotation of pasture lands, use of grazing reserves, and building watering points (boreholes); as well as to work with technical personnel for rangeland management. In reality these associations accomplished little. And there was little investigation of changes in the pastoral sector by the cooperative reforms (Laitin and Samatar 1987). There was a mismatch between grazing areas assigned to cooperatives and the needs of herds during drought when mobility was necessary. Contraction and expansion of herds with respect to drought cycles were not modified toward stable, intensified production, even though the Rangelands initiatives were designed for this (Bennett et al 1986). By 1979 the cooperative system was beginning to crowd smaller herd owners that were not members of a cooperative out of certain areas as grazing lands were increasingly enclosed--even though one objective of the cooperatives was to 
ensure that non-members had some access to pasture (Bennett et al 1986).

\section{Indigenous Pastoral Associations}

Apart from the cooperative associations, there also existed over 30 longstanding grazing associations with indigenous roots in somali social and political structures (USAID 1979; Bennett et al 1986). Before assistance of any kind was directed to these associations however, they had to conform to the Rangeland Projects' determination of what was beneficial for livestock production, including grazing restrictions and water development (USAID 1979; Bennett et al 1986). Different operational rules for grazing cooperatives and these grazing associations eventually put these institutions in competition with each other (Bennett et al 1986).

\section{Marketing}

Although marketing facilities associated with livestock development efforts were improved, they did not change the social context of pastoralism; whereby the priority was to sell the smallest number of livestock necessary to maintain and increase herd size and obtain cash needs (Al-Najim and Briggs 1992). Thus any sales increases did not reduce pressure on the rangelands (Al-Najim and Briggs 1992). Improvements in the quantity, quality, and access to range forage through implementation of grazing reserves as the primary tenurial approach, were largely unsuccessful (Al-Najim and Briggs 1992) .

\section{Effects of the National Tenure System on Indigenous Pastoralist Resource Use} Multiple Claims and Tenure Dispute Resolution

Attempted shifts from indigenous tenure systems to the state system, together with differential awareness of and access to the means for becoming involved in the state system, resulted in many instances of multiple claims to land. While there were steps within the national registration program that were intended to avoid this, namely by notifying population centers proximate to the land in question that a party was interested in registration, and by inviting all other claimants (with documented title or not) to come forward and contest the claim, this and other procedures were frequently sidestepped (Unruh in press; Samatar 1989b). Land tenure dispute resolution mechanisms were inadequate to resolve the many competing claims, and embraced a variety of means of mediation that were frequently in jurisdictional conflict (Roth et al 1987; Samatar 1989b). For pastoralists the most immediate forms of resolution comprised various traditional methods, including: settlement by personal negotiation with the opposing party, the involvement of farmers' committees, intervention by community religious leaders such as sheikhs and imams, and less often, violence. Local level administrations also took part in resolving land disputes, as did the Ministry of Agriculture at various levels, and the Somali legal system (Roth et al 1987; Samatar 1989b). The dispute resolution methods belonging to the indigenous and state tenure systems were not reconciled with each other, and so frequently operated in ways that were not compatible.

\section{Land Competition and Degradation}

Competing claims to resources, together with increased pressure on grazing resources, and increasingly constrained livestock movements, and 
worsened rangeland degradation as livestock densities surpassed the carrying capacity of areas pastoralists still had access to (LRDC 1985). This meant increased vulnerability for pastoralists and the range resources they occupied. As more arable land was registered to large farms, especially in riverine locations, transhumant herders were forced to focus dry season fodder resource access on the remaining small farms, or to utilize more marginal lands nearby usually reserved for wet season grazing. One consequence was increased competition between herders and small farmers, many of the latter having themselves been displaced from better watered locations near the river. Increased competition in the marginal zones contributed to rapid degradation of these areas. As happens elsewhere in Africa, most notably in the Sahel (Ibrahim 1978), this degradation then contributes to grazing problems during the wet season when these pastures are traditionally used, because pastoralists are forced to overgraze them during the dry season. Thus one can imagine a ripple effect in land use and ecological risk occurring over wide areas as a result of tenure changes. Overgrazing and land degradation in turn was perceived to be a serious obstacle to pastoral sector development (Krokfors 1984).

\section{Confrontation}

A deteriorating and shrinking resource base increased discord over access to adequate land and water resources (Markakis 1993). Ephemeral coalitions between lineages and their constituent units were created and abandoned in a continuing attempt to facilitate access to dwindling resources (Samatar 1993). Where agreements for access to resources could not be, or were not made due to increasing competition, use was made of areas which were previously avoided either because they were contested, or were held by several lineage units in reserve for dry season and drought grazing. This generated conflict, as did simply utilizing grazing land without permission. With less scope for making agreements, pastoralists increasingly employed aggressive encroachment and defense based on supremacy of force. In the past, the combination of dwindling resources together with territorial intrusion led to occasional clan wars (Bennett 1991). These were especially acute in the dry seasons.

As the Somaili state began to unravel in the late 1980s and early 1990s herders had increasingly to rely on force to secure access to dry season fodder and water. The alternative was the loss of their animals and a serious threat to their survival. These pressures worked to dissolve some of the longstanding arrangements of reciprocity and resource sharing that had bound small-scale farmers and pastoralists together in the past. Recourse to guns rather than to state or indigenous conflict resolution mechanisms became the means of resolving disputes over access to resources. The mobile militias which emerged in 1991 gained ready volunteers among the young, displaced pastoralists of the interior. Urged on by ambitious cliques of politicians, merchants, and elders, these armed nomads jumped into the scramble for riverine resources that increasingly had been denied them during the course of the previous decades (Unruh in press).

\section{Food Security}

Many development and government land use efforts in the country ignored how development activities affected indigenous pastoralist tenure systems which undergirded traditional grazing patterns, and the impacts that 
alterations in such patterns had on rangeland degradation and food security for the large number of pastoralists. Also not considered was the role that livestock played as a fallback food supply for agriculturalists in times of drought and crop failure (Samatar 1989b).

In many cases pastoralist self-sufficiency in somalia was eroded by modern market mechanisms which transferred the responsibility for food security to systems under control of the state or international agencies. Such a dependence can have dramatic effects when these mechanisms are disrupted by famine and conflict. This also raises the stakes connected with using food as a weapon (Hutchison 1991).

\section{The Future}

While the rehabilitation of the pastoralist sector following the upheaval of the early 1990s will necessarily play an important role in the recovery of Somalia, at the same time it presents a dilemma. Although pastoralists comprise the numerical majority in the country, there is considerable discussion as to whether anything close to a traditional pastoral strategy will be able to continue in somalia and elsewhere on the Horn (Laitin and Samatar 1987; Hutchison 1991; Baxter 1993; Morton 1993; Bennett 1991). Environmental stress, and limitations placed on migrations, along with other resource tenure changes will likely lead increasingly to inaccess to the material base for such a strategy (Korkfors 1984; Markakis 1993). Similar scenarios are being repeated in many other parts of the continent. In Somalia, disintegration of the tenurial, economic, and social tenants of indigenous pastoralism have been underway since the colonial era (Fadal 1984; Bennett et al 1986; Samatar 1989b).

In all likelihood, pressures on pastoralist grazing and watering resources will continue to intensify, even when peaceful conditions return. Riverine areas will almost certainly be targeted for the resettlement of refugees and agricultural development, and the process of supporting and subsidizing large farmers for urban food production and export will begin anew. This will pose significant constraints on utilization of these areas for dry season and drought livestock grazing. It remains to be seen if indigenous Somali pastoralism and a future Somali state will be able to accommodate each other given past incompatibilities in tenure systems, and the necessary multiple use of land and water resources. Modes of agropastoralism hold considerable potential and have existed for some time in much of central Somalia (see Massey 1987). However for variations of pastoralism to work for large numbers of people, in a way that is compatible with state objectives, future development efforts will need to pursue as a priority a workable and mutually beneficial relationship between indigenous pastoralist resource tenure and a national tenure system.

\section{References}

Al-Najim, M.N., Briggs, J.: Livestock development in Somalia - a critical review. GeoJournal 26, 357-362 (1992)

Baxter, P.T.W.: The 'new' east African pastoralist: an overview. In: Markakis, J. (ed.), Conflict and the Decline of Pastoralism on the Horn of Africa. The Macmillan Press Ltd., London. 1993. 
Bennett, J.W., Lawry, S.W., Riddell, J.C.: Land tenure and livestock development in sub-Saharan Africa. AID Evaluation Special Study No. 39. Land Tenure Center and US Agency for International Development. 1986.

Bennett, O. (ed): Greenwar: Environment and Conflict. The Panos Institute, Budapest. 1991 .

Breman, H., Cisse, A.M., Djiteye, M.A., Elberse, W.Th.: Pasture and forage availability in the Sahel. Israel Journal of Botany 28, 227-251 (1979)

Bruce, J.: Land tenure issues in project design and strategies for agricultural development in sub-Saharan Africa. Land Tenure Center, University of Wisconsin, Madison, USA. 1986.

de Bruijn, M., van Dijk, H.: State formation and the decline of pastoralism: the Fulani in central Niger. In: Markakis, J. (ed.), Conflict and the Decline of Pastoralism in the Horn of Africa. The Macmillan Press Ltd., London. 1993

Clark, J.: Debacle in Somalia. Foreign Affairs 72, 109-123 (1993)

Dornbos, M.: Pasture and polis: the roots of political marginalization of Somali pastoralism. In: Markakis, J. (ed.), Conflict and the Decline of Pastoralism in the Horn of Africa. The Macmillan Press Ltd., London. 1993.

Dyson-Hudson, N.: Pastoral production systems and livestock development projects: an east African Perspective. In: Cernea, M.M. (ed.), Putting People First: Sociological Variables in Rural Development. Oxford University Press, London. 1985.

Fadal, M.O.: The ongoing process of gradual disintegration of the traditional social and economic systems of pastoralism in somalia. In: Labahn, T. (ed.), Proceedings of the Second International Congress of Somali Studies. University of Hamburg August 1-6, 1983. Helmut Buske Verlag, Hamburg. 1984.

Gunn, S.: Somalia. In: Powelson, J.P., Sock, R. (eds.) The Peasant Betrayed: Agriculture and Land Reform in the Third World. The Cato Institute, Washington DC. 1990.

Helander, B.: The social dynamics of southern Somali agro-pastoralism: a regional approach. In: Conze, P. and Labahn, P. (eds.), Somalia: Agriculture in the Winds of Change. Saarbrucken - Schafbrucke Publishers, Germany. 1986.

Hooglund, E.: Government and politics. In: Metz, H.C. (ed.), Somalia: A Country Study. Fourth edition, Library of Congress, Federal Research Division, Washington D.C. 1993.

Ibrahim, F.N.: Combating famine by grain storage in western Sudan. GeoJournal 14,2935 (1987) 
Krokfors, C.: Environmental considerations and planning in Somalia. In: Labahn, T. (ed.), Proceedings of the Second International Congress of Somali Studies. University of Hamburg August 1-6, 1983. Helmut Buske Verlag, Hamburg. 1984.

Laitin, D.D., and Samatar, S.S.: Somalia: Nation in Search of a state. Westview Press, Boulder. 1987.

Land Resources Development Center (LRDC): Land Use in TsetseAffected Areas of Southern Somalia. Tolworth Tower, Tolworth, Surbiton, KT6 7DY, UK. 1985.

Lawry, S.W.: Tenure policy and natural resource management in Sahelian west Africa. Land Tenure Center Paper No. 130, Land Tenure Center, University of WisconsinMadison, Madison, USA. 1989.

Markakis, J.: Introduction. In: Markakis, J. (ed.), Conflict and the Decline of Pastoralism in the Horn of Africa. The Macmillan Press Ltd., London, 1993.

Massey, G.: Subsistence and Change: Lessons of Agropastoralism in Somalia. Westview Press. Boulder, Colorado. 1987.

McGowan, R., Johnston, L., Waldstein, A., Tillman, G., Speed, J.: Irrigation water lifting in the Shebelli water management project. Project Report, Associates in Rural Development, Burlington VT, USA. 1986.

Morton, J.: Pastoral decline and famine: the Beja case. In: Markakis, J. (ed.), Conflict and the Decline of Pastoralism in the Horn of Africa. The Macmillan Press Ltd., London. 1993.

Ornas, af A.H.: Pastoral and environmental security in east Africa. Disasters $14,115-122$ (1990)

Poulsen, E.: the changing patterns of pastoral production in Somali society. In: Palsson G (ed.) From Water to World-Making: African Models and Arid Lands. The Scandinavian Institute of African Studies, Uppsala. 1990.

Riddell, J.C.: Land tenure issues in west African livestock and range development projects. Land Tenure Center Research Paper No. 77, Madison, WI, USA. 1982 .

Roth, M., Unruh, J.: Land title, tenure security, credit and investment in the Lower Shabelle region, Somalia. Land Tenure Center, Madison, WI. 1990 .

Roth, M., Lemel, H., Bruce, J., Unruh, J.: An analysis of land tenure and water allocation issues in the Shalambood irrigation zone, Somalia. Land Tenure Center project report, University of Wisconsin-Madison. 1987.

Salisbury, L.: The role of livestock in the Lower Shabelle. United States Agency for International Development Somalia Mission, Mogadishu. 1988. 
Samatar, A.I.: The State and Rural Transformation in Northern Somalia 18841986. The University of Wisconsin Press, Madison, USA. 1989a.

Samatar, M.S.: A study on drought induced migration and its impact on land tenure and production in the inter-riverine region of Somalia. Food and Agriculture Organization of the United Nations, Rome. 1989b.

Samatar, S.S.: The society and its environment. In: Metz, H.C. (ed.), Somalia, a Country Study. Federal Research Division, Library of Congress, US Government Printing Office, Washington, D.C. 1993.

Scudder, T.: River basin projects in Africa. Environment 31, 431 (1989)

Storas, F.: Intention of implication - the effects of Turkana social organization on ecological balances. In: Baxter, P.T.W., Hoog, R.

(eds.), Property, Poverty, and People: Changing Rights in Property and Problems of Pastoral Development. University of Manchester,

Manchester. 1990.

Swift, J.: Local customary institutions as the basis for natural resource management among the Boran pastoralists in northern Kenya. In: Leach, M., Mearns, R. (eds.), Environmental Change: Development Challenges. IDS Bulletin, Sussex. 1991.

United States Agency for International Development (USAID) : Somalia: Central Rangeland Development. AID project No. 649-0108, Washington D.C. 1979 .

Unruh, J.D.: Resource sharing: small-holders and pastoralists in Shalambood, Lower Shabelle valley. In: Cassanelli, L., Besteman, K. (eds.), Politics and Production in Southern Somalia, Westview Press. in press.

White, C.: Changing animal ownership and access to land among the Wodaabe (Fulani) of Central Niger. In: Baxter, P.T.W., Hogg, R. (eds.), Property, Poverty and People: Changing Rights in Property and Problems of Pastoral Development. Manchester: Department of Social Anthropology and International Development Centre. 1990.

\section{Figure Caption}

Figure 1. Somali clan cross-border pastoral migrations, home areas, and home wells. Source: Samatar (1991) as adapted from Laitin and Samatar (1987). 